\title{
ONLINE ENGLISH LEARNING DURING COVID-19 PANDEMIC FOR STUDENTS OF SMA NEGERI 4 MEDAN \\ ${ }^{1}$ Febrianty Lumbantobing, ${ }^{2}$ Roganda Simamora, ${ }^{3}$ Melany Lorenza Sirait, ${ }^{4}$ Inry Surya Angelina Simanjuntak, ${ }^{5}$ Azizah Husda \\ English Language Education, University of Prima Indonesia, Medan Indonesia \\ Email: ${ }^{1}$ febriantylumbantobing98@gmail.com, ${ }^{2}$ rogandasimamora746@gmail.com, 33hellsirait@gmail.com, ${ }^{4}$ angeljuntak2@gmail.com, ${ }^{5}$ azizahhusda@ unprimdn.ac.id
}

\begin{abstract}
Online learning is one of the alternatives that can overcome the COVID-19 pandemic that is endemic in 2021. This is very troubling to the community, especially disrupting learning in schools. Students who want to learn are constrained by the outbreak of the disease, so solutions are needed to overcome these problems. The purpose of this study was to get an overview of the implementation of online learning at SMA Negeri 4 Medan as an effort to suppress the spread of COVID-19 in school. The research subjects are students of the Biology Education Study Program. Data collection is done by interviewing through zoom cloud meeting. Data analysis was carried out using the Miles \& Huberman interactive analysis technique. Weak supervision of students, limited signal in remote areas and high internet costs are challenges in online learning. However, many benefits can be obtained from online learning, including increasing learning independence, interest and motivation, and the courage to express ideas and questions. The results showed that: (1) students had the basic facilities needed to participate in online learning; (2) online learning has flexibility in its implementation and can encourage the emergence of self-regulated learning and motivation to be more active in learning, and (3) distance learning encourages the emergence of social distancing behavior and minimizes the emergence of student crowds which are considered to reduce the potential for spreading COVID-19 in the campus environment.
\end{abstract}

Keywords: Online English Learning, Overcome Covid-19 


\section{CHAPTER I INTRODUCTION}

\subsection{Background of Study}

The coronavirus started in China, which spread very quickly to 225 countries around the world. This virus is very burdensome for the activities that are usually carried out by the community, in terms of economy, tourism, education, and others. The Covid-19 pandemic has greatly disrupted segments of human life, especially in terms of education. This has happened in several countries that have decided to temporarily close schools or universities, one of them in Indonesia. The government took this policy to stop the spread of the virus because the spread of the coronavirus is very fast and its prevention is not yet known. The impact that occurs during the temporary cessation of the learning process affects the mindset of students in learning. So that educational institution are required to be able to carry out the learning process so that students and teachers can interact in the teaching and learning process without having face-to-face meetings.

The Covid-19 pandemic that is currently happening in the world has a huge impact on the wider community. Certain institutions are required to be able to carry out new movements to carry out their duties and obligations properly. Likewise, educational institutions are required to be able to make the latest innovations in the learning process carried out during the pandemic because there is no face-to-face learning process. As we know today educational institutions use an online learning system or what is often referred to as online. Educators use online classes to carry out the teaching and learning process so that face-to-face learning is not carried out to avoid the spread of the Covid-19 outbreak. The learning process during the Covid-19 pandemic uses an educational model where all activities carried out face-to-face are drastically replaced by using online from elementary school to college-level (Sadikin \& Hamidah, 2020). This has resulted in the learning process that was previously carried out directly in the classroom now using certain applications according to the needs and needs of each school. Online learning is carried out so that the prevention of the spread of COVID-19 can be carried out properly according to the government's advice and the learning process continues as usual. 
Based on the impact of the covid-19 virus that attacked the archipelago, the rules in the education system in Indonesia were recommended into the online learning system by the government. The results of the decision of the minister of education in Indonesia officially explain that all learning activities carried out in schools or colleges are carried out in their respective homes using the available applications. This policy is carried out to reduce physical contact with each other so that it can break the chain of the spread of the Covid-19 virus so that learning activities for students and students are carried out online. This condition is certainly not easily applied by the community, where parents act as second teachers for their children when doing online learning. Online learning is a learning system that uses electronic media facilities, so students can learn anywhere and anytime just by accessing applications or websites that have been provided using the internet network.

With this system, learning can be carried out in more varied ways, including audiovisual, images, and direct interaction so that learning materials are more varied (Mauly et al., 2020). Online learning that is currently being carried out can still be used in all educational circles and can run effectively, even though online learning seems sudden. Learning can be categorized as a complex system and its success can be seen from the ongoing process of a teaching and learning process. The learning process will affect the level of student success in a subject being studied. Online learning that is prioritized for students allows students to be given assignments as a means to find out the achievement or assessment of students' abilities in accepting and understanding the learning delivered by educators through an online system called online learning.

Learning from home is certainly different from learning activities at school, in addition to the existence of learning tools, learning activities are also supported by learning media to make it easier for students to understand the material. According to Indriana (2011: 15), learning media is intended to be one of the communication tools in the learning process, it is said so because in the learning process there is a process of delivering messages from educators to students. Learning media is also defined as one of the external factors that influence the success of learning activities, in general, the benefits of learning media are to facilitate interaction between teachers and students so that learning is more effective and efficient (Numiek, 2013: 94-95). 
There are several factors to consider when selecting media-appropriate learning; the accuracy with which the media is chosen will affect the effectiveness and efficiency of the learning process. The media used does not have to be expensive and modern; on the contrary, cheap and simple media that is easy to make and obtain may be more effective and efficient (Zainul, 2017:10). As a result of the pandemic Covid-19, the government implemented a new policy to halt its spread. Covid-19 is to put into action the community's call to implement Physical Distancing or to keep a one-meter distance from other people and avoid crowds and meetings, which raises the society. Furthermore, the government implemented a policy for the home, such as work from home (WFH), and any activities associated with the assembly or meeting were eliminated and replaced with online media. Circular letter on Online Learning and Working from Home to Prevent the Spread of Covid-19. The contents of this letter, one of which is off the teaching and learning activities and replaced with the learning-based network (Online) via the E-learning, can be used in a variety of educational institutions.

The coronavirus 2019 (Covid-19) outbreak has affected 215 countries worldwide, posing a challenge for educational institutions, particularly schools. To combat Covid-19, the government has prohibited crowding, social restrictions (social distancing), and maintaining physical distance (physical distancing), as well as wearing a mask and always washing your hands. The government has ordered the college to hold lectures or online learning rather than face-to-face lectures (via the Ministry of Education and Culture). The college is being guided to be able to organize online or online learning.

This online learning activity implemented in society can reduce the interaction between teachers and students in terms of establishing social relationships, such as in solidarity between humans, empathy, and caring. Online learning that takes place for students certainly has a difference that is felt by students compared to face-to-face learning as usual. Learning from home is certainly different from learning activities at school. The existence of a structure of learning activities that are supported by learning media has the aim of making it easier for students to understand the material. The intended learning media is one of the communication suggestions in a learning process which is the delivery of messages from educators to students (Lu'lu Ul Janah, 2016). This learning media is certainly very helpful in the continuity of a learning 
process so that students understand more easily and can more leverage in achieving a learning goal. However, learning activities at home certainly require learning strategies that are suitable for students so that students can more easily understand the materials being taught. With the current conditions, the learning media that will be used by online students is certainly difficult to do, this is because parents act as educators for students who are less experienced in delivering material or in guiding students in learning.

The application of online learning is carried out with media such as smartphones, laptops, and other media that can be connected to the internet. The process of learning English online is carried out using several applications and websites that link communication between teachers and students. Senior High School 4 teacher, Mrs. Herlina said "the teaching and learning process begins with virtual face-to-face using the zoom application, and assigns assignments via WhatsApp chat". Learning begins using the zoom or googles meet application to conduct face-toface meetings between students and teachers through a virtual world. The teacher explains the material to students directly when zooming in, learning takes place as is usually done in in-person meetings. After the meeting hours are over the teacher gives assignments to students as usually through other applications such as chat WhatsApp groups, and collected virtually also through chat WhatsApp groups as well. Therefore, learning runs normally, like previous face-to-face learning. All levels of education have a negative impact because students are "forced" to learn from home (Purwanto et al., 2020). However, online learning will seem complicated for some teachers and students who do not understand technology. Online learning has drawbacks that make it difficult for students, parents, and teachers alike. In the continuity of this learning, of course, there are obstacles in the applicator and network, because there are some children who come from underprivileged families and are constrained in some areas that do not have a good network. This requires both teachers and students to be able to solve quite complex problems and currently have not found the right solution. Therefore, the teacher cannot help students who do not have smartphones against underprivileged students, and the network cannot be tackled by the teacher directly so that many students lag in their learning.

Besides that, learning English online certainly has advantages students, and teachers may feel as well. Online learning that is applied can help teachers and 
students in mastering technology that may have been poorly understood before, and can easily access learning sites anywhere and anytime (Mauly et al., 2020). This is very beneficial for teachers and students because in today's era technology is growing rapidly which requires us as humans to participate in the current developments. Besides, online learning is also a practical and flexible way. That is, with online learning the interactions that occur between educators and students are more practical and do not have to meet. And reducing the mileage on the way to seven school places also saves time and transportation costs for students and previous teachers. However, the more important advantage is to pay attention to government protocol rules, namely to maintain a distance from each other to cut off the spread of the virus that attacks the world to maintain the health of the nation.

Strategies that can be applied to learning during the Covid 19 pandemic, namely online learning, have the benefit of continuing online teaching and learning activities, namely by using internet network media. Following the procedures for implementing online learning, the teacher carries out an obligation in teaching and providing material to students online and students do not need to come to school to carry out learning according to the curriculum. SMA Negeri 4 Medan is a school that implements an online learning system following government recommendations at every level of education. In this case, the researcher conducted an impact analysis of online learning on high school students at SMA Negeri 4 Medan.

\subsection{The Problems of the Study}

Based on the background above the problem of the study is formulated as follows:

a. How is the online English learning applied during the covid 19 pandemics at SMA Negeri 4 Medan?

b. What are the strengths and weaknesses of applying English learning?

c. Why should online English learning be applied during the covid 19 pandemics?

\subsection{The Objectives of the Study}

This study was conducted to determine the ongoing process of online English learning which was carried out at SMA Negeri 4 Medan during the current Covid-19 pandemic. Knowing the advantages and disadvantages of applying online English learning to students. So that it can find out where the error is to be corrected again so that it can run well. So that online English learning can be applied optimally so that 
students can more easily understand and enjoy the learning process. Allowing parents to be more maximal in educating and paying attention to students in learning English, fun and not burdensome learning process, and getting more attention from parents will refer to the enthusiasm of students who are more persistent in learning and show their abilities.

The impact of online English learning on teachers, students, and parents. To maximize the return of online English learning to teachers and students and parents, it is a good idea to teach their children at home. The data that researchers collected from interviews with the object under study were used as a medium in learning English for students to find out the impact of the online learning process obtained from the results of interview analysis. Therefore, it can provide new learning methods to facilitate online English learning for students and teachers as well as to better assist parents in educating and directing children in online learning from home.

\subsection{The Scope of the Study}

This study focuses on the impact of online English learning on students, knowing how to apply strengths and weaknesses, and implementing online Englishbased learning during the COVID-19 pandemic at SMA Negeri 4 Medan. The technique used by researchers in conducting research and data collection is an interview technique conducted on teachers and students of SMA Negeri 4 Medan. In the next step, researchers who have obtained the data then poured it into online English learning in the field of SMAN 4 during the covid19 pandemic. The limitation of this research lies in the aspect of collecting data, namely not all teachers can be interviewed and asked to answer questions regarding the continuity of online learning at SMAN 4 during the COVID-19 pandemic.

\subsection{The Significance of the Study}

The benefits of conducting research analysis on the impact of students' online English learning have deep meaning for students, teachers, parents, and other researchers. This research will contribute theoretically and practically. Based on the theoretical benefits, it is hoped that this research will be able to provide information and knowledge to students and researchers. For practical purposes, this research is expected by teachers to support and complement a good online English learning pattern for students. Students who initially did not have an interest in online learning because of the lack of explanation of the material they were working on were 
understandable and it was hoped that this research could attract students' interest and help teachers in better teaching patterns in online English learning. Based on this research, students are expected to improve learning outcomes through online learning. Parents are expected to be more supportive and strive so that their children get a better education during the current online English learning period by helping encourage children's interest in learning. Either by motivating children, monitoring children in learning more, and also always asking their children's activities and tasks. So, children carry out their learning and can do their job well

\section{CHAPTER II RESEARCH METHOD}

\subsection{Research Design}

To find out the impact of online English learning during the Covid-19 pandemic, the researchers used a qualitative descriptive research approach. Qualitative research is a procedure used in a study to produce descriptive data in the form of written or spoken words from the observed object and aims to analyze phenomena that occur and are experienced by research subjects and understand individual views in finding, discovering, and explaining the processing process. indepth about the subject in research (Pratiwi, 2020). One type of qualitative descriptive research is research with a case study approach. This research approach focuses on cases that are carefully observed and analyzed so that an accurate conclusion will be obtained (Muhlisian, 2013). The analysis in this study emphasizes an in-depth process to find out the impact of online English learning during the Covid 19 pandemic for high school students. In addition, descriptive qualitative research is a research process that emphasizes understanding methods that investigate social phenomena and problems in society. In this research approach, the researcher makes a complex description of online English learning during the Covid 19 pandemic, explains the advantages and disadvantages of online English learning, and provides accurate reasons to apply online English learning during the pandemic.

The data in this study are in the form of utterances/perceptions obtained from the object studied by the researcher on teachers, students, and parents. The expression 
came from interviews conducted by researchers on the object under study about online English learning during the Covid-19 pandemic which included how the learning process was, finding advantages and disadvantages in the application of online English learning, and knowing the reasons why online English learning was applied during a pandemic. covid-19 at SMA N 4 MEDAN. The data sources in this study were obtained from students, teachers, and parents who were used as real materials to obtain data orally and in written in online English learning during the Covid-19 pandemic.

\subsection{Instrument of Collecting}

Instruments are tools used by researchers to collect data in a study. The instrument used in this study was an interview. Data collection by interview is a technique used to obtain information from respondents or sources which is carried out directly between the two people concerned. In this case, the researcher conducted interviews with resource persons to obtain accurate data regarding the impact of online English learning during the Covid-19 pandemic.

This data collection technique is carried out, to obtain accurate data, researchers must use appropriate data collection techniques and aim to obtain data under the object of research. The data collection techniques used in this study are as follows:

\subsubsection{Observation}

This interview was conducted to find out how the process of learning English online during the Covid-19 pandemic. As for the preparation of researchers to conduct interviews with resource persons to obtain accurate and detailed data and information. After finding sources, researchers introduced themselves, asked permission, and determined the time and place of the interview. When conducting an interview, a person records the information obtained from the source. If there is unclear information, it can be given to the interviewer to ask for a clearer explanation from the source. Provide tools and materials needed during interviews such as; Notes, and recording devices and prepare carefully before conducting interviews with resource persons. The questions that have been provided by researchers to interview predetermined sources to obtain data and information from the informants are as follows: 


\section{A. List of Questions for Teachers}

\begin{tabular}{|c|l|}
\hline 1. & Does the teacher explain the English material well during online learning? \\
\hline 2. & Is the English material delivered by the teacher under the syllabus? \\
\hline 3. & Do teachers do questions and answers to students? \\
\hline 4. & Was online English learning effective during the Covid19 pandemic? \\
\hline 5. & How were students active in taking online learning during the Covid19 pandemic? \\
\hline
\end{tabular}

\section{B. Questionnaire for Students}

6. What do you think about online learning?

7. Do you often ask questions to the teacher when you have difficulty learning online?

8. Are you diligent in doing assignments during online learning?

9. Did your English skills improve during online learning?

10. How the online learning system is applied to students?

\section{List of Questions for Parents}

6. What is your response to your child in online learning?

7. Has this home study helped your child's learning process?

8. Has your child's achievement improved during the Covid19 pandemic?

9. What is your complaint about online learning?

10. What are your efforts in guiding children during online learning?

\subsection{Technique Analyzing Data}

In this research, the technique used to analyze the data is the descriptive qualitative data analysis technique. According to (Miles, Huberman, Saldana, 2014), that in qualitative research the data used are facts that have been collected and examined directly in the field. The data analysis carried out must be reasonable and acceptable to the mind and can be formed into hypotheses or theories. This analysis aims to determine the development of research results. The qualitative data analysis technique was obtained from non-test data, namely interviews. In this case, the data obtained from the results of the interview was carried out by conducting direct interviews with teachers, students, and parents about learning English online to students in the Covid-19 pandemic era. The indicator used to determine the impact analysis of online English learning on high school students is how online English learning was applied during the Covid-19 Pandemic at SMA N 4 Medan, knowing what the advantages and disadvantages of online English learning are applied to 
students, and to find out why online English learning should be implemented during the Covid-19 pandemic.

The following are the stages of the data analysis stages, including.

The interactive model is called the following:

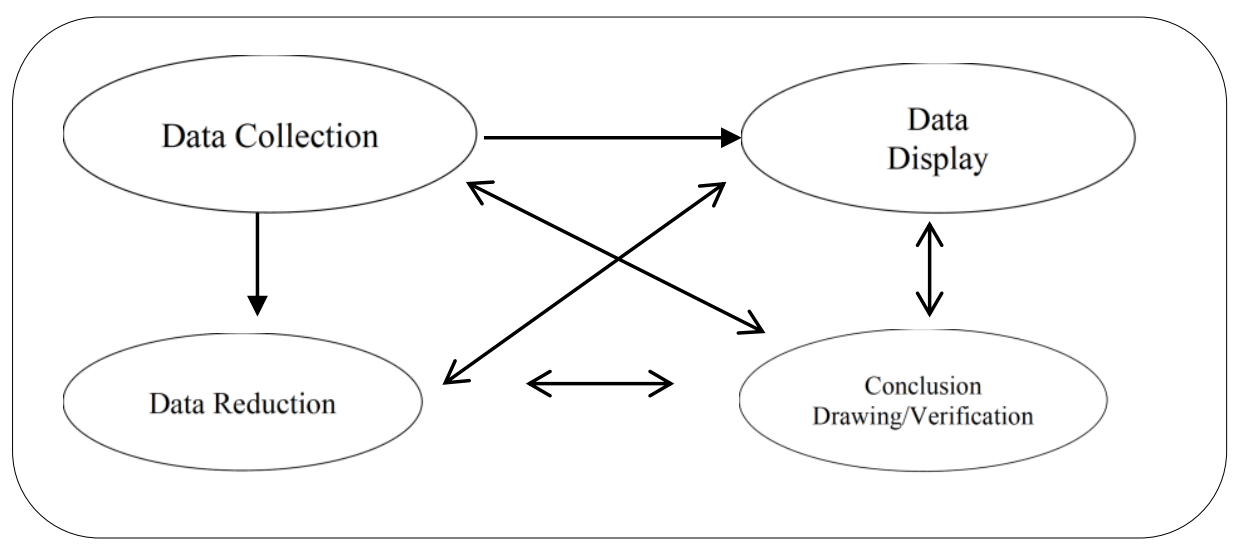

Model Data analysis: Miles and Huberman (Miles, M. B., Huberman, A. M., \& Saldaña, 2014).

The components of the interactive model data analysis are explained as follows:

\subsubsection{Data Reduction}

Data reduction is an activity of selecting data or summarizing and selecting main things and focusing on important things. This is done so that the data that has been reduced will provide a more detailed picture and can make it easier for researchers to collect further data and make it easier for researchers to classify data. In this stage, the researchers conducted data reduction by summarizing the data obtained from interviews to obtain information about the impact of online learning on high school students during the Covid-19 pandemic and summarizing the data from interviews with respondents about online learning applied to students.

\subsubsection{Data Display}

Data presentation is a systematic data collection of research results structured about information that can provide the possibility to draw conclusions and take action. The presentation of the data used in this research is qualitative research in the form of descriptive which is a description of the 
information about the characteristics or descriptions of an object. The data in this study can be presented in tabular form which can make it easier for researchers to master and understand the objectives of the study. The data presentation is then compiled in the form of a description of the research results obtained.

\subsubsection{Conclusion}

The conclusion is the result of research that answers the formulation of research problems based on the results of data analysis. These conclusions are presented in descriptive form based on data obtained from interviews conducted with selected sources. Based on the formulation of the problem that has been determined by the researcher, accurate results will be obtained about the impact of online English learning on high school students, knowing the responses and efforts of teachers or educators, and parents in addressing the sustainability of the online English learning process that is implemented in schools. The data processing process begins with collecting data during the interview then reducing the data and presenting the data until the conclusion is drawn. The procedures carried out in this study were carried out under predetermined stages to obtain data that met the validity criteria of a study. 


\section{CHAPTER III}

\section{DATA ANALYSIS, FINDINGS, AND DISCUSSIONS}

The purpose of this study is to describe online learning held at various schools throughout Indonesia as an effort to suppress the chain of the spread of Covid-19 in the college environment. Online learning referred to in this research is learning to use media learning media that can be accessed using the internet service. The research was done by first surveying the students about the implementation of online learning. Survey propagated using the google form provided to the student through WhatsApp messages. There are 100 of those subjects that have been given a response to a distributed survey. The results of the survey were then grouped into the three categories of the response of students: (1) Agree with the adoption of online learning; (2) does not agree with the adoption of online learning; (3) is not happy and dubious online learning can have a negative impact.

The subject of research is one of the students scattered in Indonesia who has been implementing online learning, and are grouped by the response of the subject of the research. Get 12 people subject research, 4 students from 2018, 4 students from the class 
of 2020, and 4 students from 2019, 8 students of the male sex, and 4 students of the female gender. Data collection was done through interviews via telephone or zoom cloud meeting. The aspects that are asked in the interview are (1) facilities and infrastructure owned by the students to carry out online learning; (2) the Response of students about the effectiveness of online learning; (3) the implementation of online learning to break the chain of the spread of Covid-19 in the college environment.

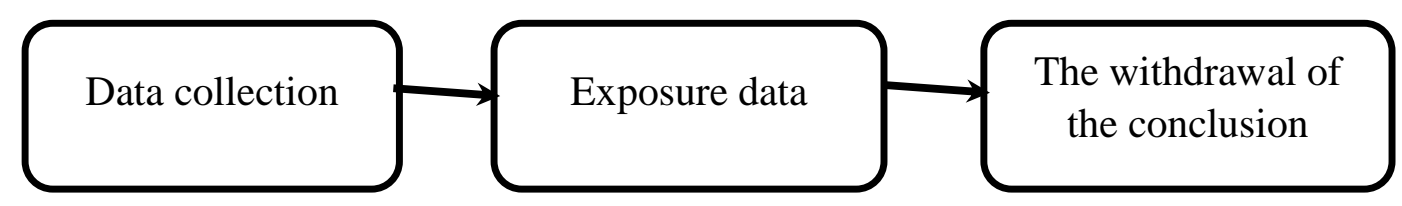

Figure 1: Stages of the research data Analysis

Stage collects all the required information from the results of the interview and then grouped the data. Exposure data needed in the study and who do not need to be thrown away. Stages of withdrawal and verification of the conclusion are the stage interpretation of data research for the drawn conclusion based on the base of the phenomenon are obtained.

\begin{tabular}{|c|c|c|l|}
\hline Num. & \multicolumn{2}{|c|}{ Percentage of online learning } & \multicolumn{1}{c|}{ Explanations } \\
\hline \multirow{2}{*}{ Agree } & $\mathbf{6 7 \%}$ & $\begin{array}{l}\text { Learning takes place online } \\
\text { through the internet, all } \\
\text { learning materials are } \\
\text { provided through the internet, } \\
\text { and according to the students } \\
\text { that learning on the internet } \\
\text { is very exciting. }\end{array}$ \\
\hline \multirow{2}{*}{} & Disagree & $\begin{array}{l}\text { According to the students } \\
\text { learning done in a face-to- } \\
\text { face or learning directly } \\
\text { because at the time of the } \\
\text { online many students are } \\
\text { constrained by the signal is } \\
\text { better-done face to face so }\end{array}$ \\
\hline
\end{tabular}




\begin{tabular}{|l|l|l|}
\hline & & $\begin{array}{l}\text { that the power capture } \\
\text { students directly }\end{array}$ \\
\hline
\end{tabular}

The challenge of learning online is the availability of internet services. Most students access the internet using the service provider, and a fraction using the WiFi service. When the policy learning online is applied at SMA N 4 MEDAN, students return home. They have difficulty cellular signal when in each area, even if there is a signal obtained very weak. This is a challenge in the application of online learning at school. Online learning has drawbacks when the internet service is weak, and instruction faculty are poorly understood by the students. The presence of online learning for students has a significant influence because it is obtained by qualitative and quantitative methods of presentation of students $67 \%$ agree and $56 \%$ disagree, it can be concluded that the higher the percentage of online learning according to students who learn online completely not through face-to-face can help students better understand the use of the internet while students who disagree reasoned that learning is done face-to-face or direct learning because when online many students are constrained by signals, it is better to do face-to-face so that students' grasping power is direct.

The increase in internet use in Indonesia is influenced by the development of information and communication technology. In 2018 there were $62.41 \%$ of the Indonesian population owning a mobile phone and $20.05 \%$ of households owning a computer at home. The data is relevant to the results of the study which explains that although there are students who do not have laptops, almost all students have smartphones. The survey conducted reported that 54 people own smartphones and laptops, and 42 people own smartphones.

The use of smartphones and laptops in online learning can improve student learning outcomes. There are many advantages of using information and communication technology in the implementation of online learning that is not bound by space and time. Many studies have been conducted on the use of devices such as smartphones and laptops in learning. The ability of smartphones and laptops to access the internet helps students to participate in online learning. The use of online learning using zoom cloud meetings has the advantage of direct interaction between students and lecturers as well as teaching materials but has the disadvantage of wasteful quota and less effective if there are more than 20 students.

Another challenge is the obstacles faced in financing online learning. Students revealed that to take part in online learning, they had to pay quite a lot to buy an internet data quota. According to them, learning in the form of video conferencing consumes a lot of data 
quota, while online discussions through instant messaging applications do not require a large quota. The average student spends IDR100.000 to IDR200.000 per week, depending on the cell phone provider. The use of online learning using video conferencing is quite expensive.

The strengths and weaknesses of applying English learning were with English onlinebased learning, students are not constrained by time and place where they can follow the lectures of each house or place anywhere. Teachers found out that in addition to learning, students are also using the devices to social media and watching youtube. Social Media has entered the realm of life group early adulthood. Students access social media for selfexpression, build friendship networks and opinions. It is unfortunate, many people addiction devices by using them in excess. To worry about the influx of information that is misleading and not attention during learning due to play the social media. In addition, learners who are addicted devices have the problem of academic and social. Learners who have an addiction to gadgets have emotional and behavioral problems.

Online learning also has its advantages to foster self-regulated learning (self-regulated learning). The use of the online application can improve independent learning online learning is more student-centered causing them to bring up the responsibility and autonomy in learning (learning autonomy). Learning online demanding the students to prepare their learning, evaluate, organize and simultaneously maintain motivation in learning online learning can increase the interest of learners.

With online learning, lecturers give lectures through virtual classes that can be accessed anywhere and anytime not bound by space and time. This condition allows students to freely choose which courses to take, and which assignments to do first. The flexibility of time, learning methods, and places in online learning affect student learning satisfaction.

The research results that were found to be unique from this study were that students felt more comfortable in expressing ideas and questions in online learning. Following learning at home makes them not feel the psychological pressure from their peers that they experience when participating in face-to-face learning. The absence of lecturers directly or physically also causes students not to feel awkward in expressing their ideas. As a result, physical limitations, as well as limitations of space and time, make students more comfortable in communicating. Furthermore, online learning eliminates awkwardness which in the end makes students dare to express themselves in asking questions and expressing ideas freely. Online learning has its challenges, the location of students and lecturers being separated when carrying out learning causes teachers to not be able to directly supervise 
student activities during the learning process. There is no guarantee that a student listens to a teacher's review. reported in his research that students dream more often in online lectures than during face-to-face lectures. Therefore, it is recommended that online learning be held in a not too long time considering that students find it difficult to maintain concentration if online lectures are carried out for more than one hour. The results of the study also reported that not a few students had difficulties in understanding lecture material given online. Teaching materials are generally delivered in the form of reading that is not easily understood by students thoroughly. They assume that the materials and assignments are not solely due to the need for a direct explanation by the teacher. Class lecturers often come in and provide explanations, providing better learning compared to classes where teachers rarely come into class and provide explanations

\section{CHAPTER IV CONCLUSION}

\subsection{Conclusion}

The outbreak of the 2019 coronavirus (Covid-19) which hit 215 countries in the world presents its challenges for educational institutions, especially universities. To fight Covid-19, the government has banned crowds, social distancing, and physical distancing, wearing masks, and always washing hands. The results showed that students had the facilities and infrastructure to carry out online learning. It can be concluded that students feel that face-to-face lectures or in such classes are usually considered more optimal and the presentation of the material provided by lecturers is much more acceptable than online or online lectures which have several obstacles and obstacles for some students so far. Because of these many obstacles, the government should be able to make it a benchmark for the development of education by students, especially students in Indonesia. Students experience obstacles, or an unstable network when online classes are very depressed in 
absorbing the material provided by the teacher resulting in the material being delivered by the lecturer not being optimal and some students also having difficulty doing group assignments which require students to understand the material well plus students who feel difficulty using online meeting applications for group assignments. Students admit that they don't always check or hold their cellphones because they are busy with their families, this results in a waste of time wasted just because of this problem, which should be done on time, not delayed because some students are not disciplined in doing the tasks given by the teacher As a result, the completed task does not achieve the goal or is not done optimally and can affect student grades of course. This can affect students' scores on the upcoming final semester exams. Because the material is not delivered and the work done is not optimal, it is feared that students will get final grades or their GPA will decrease this year. This can affect the quality of universities in several regions in Indonesia. For this reason, student awareness is needed to improve the learning process outside of class hours, this aims to enrich students' understanding of the material to be given and the tasks given by the lecturer to maintain the stability of each student's grades. Here are some efforts that can be made in student-managed lectures online or online, namely as much as possible to focus on understanding the material presented by the lecturer, if there is a technical error or unstable network, try not to panic and stay relaxed and wait until the network is stable and can follow the lecture again after that ask your friends if there are points that are not understood or can hold group discussions with friends to better understand the material when working on group assignments, students must be disciplined in their work and take responsibility for completing them well. That's an effort that can be done by students while running online or online lectures. This effort aims to reduce students' barriers to online learning. The Covid-19 pandemic, which is expected to spread to students and the wider community, can carry out their activities as usual. We as humans can only hope that it will happen as soon as possible given the many impacts that have occurred due to COVID-19.

\subsection{Suggestion}

With this research, it is hoped that parents can work together with teachers so that students can control teaching and learning activities even though it is only online. Teachers are expected to be able to provide good lessons online and always provide instructions for students to study well even if only at home. 


\section{REFERENCES}

Abidin, Z. (2020). The implementation of Problem-Based Learning, Project-Based Learning Literature, and Inquiry Learning in Improving the Ability of the Connection Mathematically. The Profession Of Basic Education, 7(1), 3752.http://doi.org/10.23917/ppd.v1i1.10736

Anggrawan, A. (2019). Descriptive analysis of Learning Outcomes Learning face-to-Face and Online Learning According to the Learning Styles of Students. MATRIX: Journal of Management, Informatics And Computer Engineering, 18(2), 339-346. https://doi.org/10.30812/matrik.v18i2.411

Arifa, Fierka Nurul (2020). Challenges To The Implementation Of The Policy Of Learning From Home In The Event Of An Emergency Covid-19. Short Info, 7(1), 13-18.

Goddess, WAF (2020). The impact of Covid-19 On the Implementation of Online Learning 
in the Primary School. Journal Of Science Education, 2(1), 55- 61. https://doi.org/10.31004/edukatif.v2i1.89

Eveline. (2010). Learning theory and Learning. Ghalia Indonesia

The Word Sari Rahayu Rahman (2020). Online learning Amid the Pandemic Covid-19. Indonesian Journal of Educational Science (IJES), 2(2), 81-89.

Gunawan, Suranti, NMY, \& Fathoroni. (2020). Variations of Models and Learning Platforms for Prospective Teachers During the COVID-19 Pandemic Period. Indonesian Journal of Teacher Education, 1, 61-70.

Herliandry, LD, Nurhasanah, Suban, ME, \& Heru, K. (2020). Learning On The Pandemic Of Covid-19. Journal Of Educational Technology, 22(1), 65-70. https://doi.org/https://doi.org/10. 21009/jtp.v22i1.15286

Nadziroh, F. (2017). Analysis Of The Effectiveness Of The Learning System. Journal Of Computer Science And Visual Communication Design (Jikdiskomvis), 2(1), 1-14.

Prastowo, A. (2012). Qualitative Research Methods In The Perspective Of Research Design. Ar-ruzzmedia.

Putria, H., Maula, LH, \& Uswatun, DA (2020). The analysis of the Learning Process In the Network (Online) The Pandemic of COVID-19 on Elementary School Teacher. Journal Basicedu, 4(4), 861-872. https://doi.org/10.31004/basicedu.v4i4.445

Rohmawati, A. (2015). The Implementation Of Learning. Journal Of Early Childhood Education, 9(1), 15-32.

Rusman. (2012). Learning and Computer-Based Learning. Alphabet.

Sadikin, A. \& Hamidah, A. (2020) Online Learning Amid the Outbreak of Covid19. BIODIK, 6(02), 214-224. https://doi.org/10.22437/bio.v6i2.9759\}

Sanjaya, W. (2009). Class Action Research. Kencana

Sudirman, S. (2002). Study Assessments about the Possibility of the use of the Internet for Learning in SENIOR high schools in Jakarta and its Surrounding areas. Research and Development agency - the Ministry of National Education. 